\title{
[When Nature Triggers Trauma: Environmental Racism and Ecofeminism in Zora Neale Hurston's Their Eyes Were Watching God]
}

\section{Karla Rohová}

\section{University of Ostrava,} Ostrava, Czech Republic

[Abstract] This paper deals with the depiction of environmental racism, natural trauma and the woman/nature or woman/animal relationships in Zora Neale Hurston's novel Their Eyes Were Watching God. The main goal is to identify and critically evaluate the impacts of such depictions or relationships in the context of the systemic oppression of African American women and men in the United States of America. For this purpose, excerpts from throughout the novel are discussed with regard to their depiction of dehumanization, animalization, natural trauma, or the metaphor of the female body, with the emphasis on ecofeminist and ecocritical aspects in Hurston's work.

[Keywords] environmental racism, ecofeminism, ecocriticism, critical race theory, animalization, Zora Neale Hurston, Their Eyes Were Watching God, dehumanization, natural trauma 


\section{[1] Introduction}

In her collection of essays, Alice Walker argues that it is not only women, people of color and poor people who face systemic oppression and exploitation, but that "Earth itself has become the nigger of the world" (47). Through her words, Walker equates the pain of the world's most oppressed people to the pain of our planet, and consequently the natural environment. However, Walker is not the first African American female writer who has drawn this parallel. Zora Neale Hurston's Their Eyes Were Watching God (1937) has been revealed as a source of inspiration to nature writers such as Walker herself, and it should not be surprising that for Hurston, much like for Walker or Steinbeck, the natural environment is vital to the story as it is an active object, sometimes almost a character in its own right, which is used to describe the characters' journey and highlight the struggles of (not only) African American communities.

Born in Alabama and raised in Eatonville, Florida, the first all-black town in the United States, Hurston based her novels on celebrating the culture and community of the rural - and Black - South, and rejected the need to write about urban life in order to portray the success of African Americans in the city; she thus represented an opposite pole in African American literature (Hemenway 52-54). Moreover, Hurston never rejected African American folklore, even though her affiliation with the folk tradition made her an easy target for critics such as Richard Wright; the unfortunately vilified Hurston had to wait for the publication of Walker's essay "In Search of Zora Neale Hurston", published in 1975, before she was reappraised in literary circles and among critics as well as by the general public. While critical discussions used to focus predominantly on justifying or, on the other hand, criticizing Hurston's inclusion in the Harlem Renaissance, or on whether her use of folk traditions was harmful or not, this paper rather aims to contribute to discussions about preventing and solving the interconnected injustices committed against people and the natural environment; it thus deals with the novel's portrayal of nature, race and gender.

This paper evaluates the portrayal of environmental racism in Hurston's novel Their Eyes Were Watching God, with the goal of identifying animality and subsequent natural trauma, as well as evaluating these concepts in the historical, political and social context of environmental and institutional racism in the United States of America. In order to do so, not only ecocritical but also ecofeminist perspectives are applied, as the latter offers a unique opportunity to further evaluate the centuries-old connection which stigmatizes people of color (especially Native Americans and African Americans) as being closer to nature, yet allows them no control of it, and thus renders people of color as objects that are vulnerable to being controlled, colonized, exploited and degraded in the same manner as nature.

\section{[2] Natural Trauma and Dehumanization}

Written more than 80 years ago, Their Eyes Were Watching God depicts a journey towards an African American woman's self-discovery and empowerment through nature and 
against the background of natural disaster, trauma and racism present in the Deep South following its history of slavery. Both folk culture and the setting of Hurston's novel are vital instruments in understanding Hurston's focus on and use of nature as a non-passive object. African American folk culture "becomes a major instrument of survival" in the novel; at the same time, Hurston uses the woman/nature metaphor and her characters' relationship with the natural world in order to challenge the degrading way in which African American people - and women in particular - are associated with and exploited through nature (Hemenway 54). In Hurston's hands, nature also becomes instrumental; it is not only a medium of survival, but above all a medium of confrontation and transition (Stein 146-147).

The novel has an African American female protagonist who undertakes an eventful life journey starting in her teenage years. Janie, born to an African American mother (symbolically named Leafy after she is raped in the woods by a white schoolteacher), is raised by her grandmother Nanny in West Florida due to her mother's absence. As Janie reaches her sixteenth birthday, her grandmother weds her to John Killicks. In Nanny's words, Killicks is an ideal husband for Janie, as he "[g]ot a house bought and paid for and sixty acres uh land" and "[d]at's de very prong all us black women gits hung on" (Hurston 20).

However, Janie's perspective is different. While still in the care of her grandmother, she prefers to spend time in their garden. It is in the natural environment that Janie seems to acquire the best understanding of herself. This free exploration of nature and oneself stands in direct opposition to Nanny's experience of slavery and subsequent injustice in the form of the racism and sexual exploitation which stand behind Nanny's association of nature with trauma. This distinction between Nanny and Janie's connection to nature strongly relates to the legacy of slavery in the American South - and Janie's grandmother is, without a doubt, representative of the trauma associated with it.

To be able to better understand the origins of Nanny's natural trauma, it is necessary to briefly explore the social and historical background of the time when Nanny was afflicted with this trauma. Following the abolition of slavery and the end of the Civil War, the South and its plantations were stripped of all their fertility and subsequent agricultural know-how. In particular, the plantations were mostly abandoned or destroyed, no longer considered the "racial Eden" of the country (Outka 85); deforestation accelerated, and a significant number of animal species found in the South were hunted in an uncontrolled manner and thus became extinct - a picture of nature that one would more likely associate with industrialized parts of the country or, in reference to Octavia Butler's Parable of the Sower (1993), a post-apocalyptic scene. In fact, Paul Outka argues that "[t]here was little 'pure' nature to associate with in the postbellum South" (96). Such consequences were, of course, deeply reflected in the Southern landscape - not only the landscape to which African American people, including Janie's grandmother, had been unjustly bound for several centuries due to slavery, but also the landscape by which they were unjustly limited even after gaining their freedom, due to the environmental aftermath of the Civil War. 
For former slaves like Nanny, nature is a trigger of "primary historical trauma", as it is a reminder of a life spent in slavery, being exploited and degraded through their association with nature, frequently raped in the outdoors, with no access to or chance to enjoy white people's "pure" nature (Outka 187). Instead of finding freedom following the Civil War, Nanny experienced more years of being bound to an environmentally destroyed land, with no opportunity to live off its former richness. Thus, Nanny's natural reaction is "to disassociate from nature altogether", as she wishes to avoid the natural trauma triggered by nature, or to avoid the grief caused by her lost ability to enjoy nature because of that trauma (Outka 187).

However, the trauma that nature may trigger - a trauma that Nanny suffers from and passes onto Janie - is still reflected in environmental racism in the United States today. In fact, Ruffin reflects on the fact that African Americans have been alienated from nature and the environmental justice movement, and are still considered "the environmental others" (2):

[I]t is the coupling of racism and ecological alienation. The de facto reservation for whites of a prime environmental resource... is indicative of a larger national pattern that has criminalized African Americans as "environmental others" (Washington, Packing Them In, 22) whose very presence in natural or built environments is cause for concern. (2)

While Ruffin describes this ecological alienation of the present time, her critical thoughts, combined with Outka's description of the origin of trauma and its relation to slavery in the Deep South, could also be applied to how Hurston's characters perceive nature as well as how they are alienated from their environment through the racist structure that positions African American people in an unjust place within a social hierarchy - a positioning which, in consequence, keeps them away from "the beauty and solace of the natural world" (Outka 187, Ruffin 1-6).

The distinction between how Janie and her grandmother view nature is well demonstrated throughout the whole novel. It begins with Janie's use of the imagery of trees to describe how she "saw her life like a great tree in leaf with the things suffered, things enjoyed, things done and undone" (Hurston 11). This comparison, though metaphorical, is the first indication of Janie's powerful relationship with trees and the natural environment. By describing her life as "a great tree in leaf", Janie indicates that despite downfalls, she is able to live a flourishing life, just as trees are able to bloom after a dreadful winter. At the same time, this description suggests that Janie is aware of the cycle of life which is ever-present in nature (indeed the symbolism of trees supports this suggestion). When it comes to Nanny, Janie also describes her using tree imagery; however, she does so in a strikingly contrasting manner: "Nanny's head and face looked like the standing roots of some old tree that had been torn away by storm" (Hurston 13). Considering Nanny's experience of slavery, it should be no surprise that she had been "torn away by storm" (Hurston 13). Nanny herself uses a similar way of describing the lives of Black people to Janie, saying that "[y]ou know, honey, us colored folks is branches without roots and that 
makes things come round in queer ways" (Hurston 15). While doing so, Nanny places African American people outside the cycle of life, outside the days of bloom, and above all outside nature, and demonstrates that she sees herself - and "us colored folks" - as "environmental others" (Ruffin 2).

However, trees also play a role in a far more detailed scene of Janie's union with nature - one that is demonstrative of Janie's discovery of her own sexuality:

She was stretched on her back beneath the pear tree soaking in the alto chant of the visiting bees, the gold of the sun and the panting breath of the breeze when the inaudible voice of it all came to her. She saw a dust-bearing bee sink into the sanctum of a bloom; the thousand sister-calyxes arch to meet the love embrace and the ecstatic shiver of the tree from root to tiniest branch creaming in every blossom and frothing with delight. So this was a marriage! She had been summoned to behold a revelation. Then Janie felt a pain remorseless sweet that left her limp and languid. (Hurston 12)

In this excerpt, preceded by a scene in which Janie feels herself becoming one with nature, as the images she perceives in the garden "buried themselves in her flesh" (Hurston 33), Hurston aptly uses the woman/nature metaphor to symbolize the start of Janie's "quest for erotic and emotional freedom" (Outka 188). At the same time, this scene of an ecological exchange - marriage - in nature, which Janie observes and, based on her own emotional response, also analyzes, guides Janie to understand that at the core of the relationships and bonds in nature is equality; through this "marriage", as Janie calls it, living objects are dependent on each other (Aquilone 4-5). Simultaneously, as Janie experiences this scene as being a part of the marriage, she learns that "[h] uman and natural are merged, not hierarchically separated" (Stein 74).

In fact, this experience under the pear tree remains crucial for Janie throughout the rest of her journey. According to Ines Casa Maroto, Janie attempts to place "her own experience into harmony with her initial vision of the pear tree" (72). In other words, from this point in her life, this moment which not only awakens Janie's sexuality but also becomes the roots of her own identity, Janie compares every relationship in her life to the images that she has witnessed in her grandmother's garden, under the pear tree. The first time this happens, and when Janie becomes disappointed, even asking "[w]here were the singing bees for her?" (Hurston 13), is when Janie compares her epiphany to how isolated from the rest of the world she feels while living with her grandmother.

While this awakening of Janie's sexuality is used to mark the beginning of "her conscious life" (Hurston 12), Hurston, with the use of the woman/nature metaphor, plants more epiphany-like moments of this kind throughout the novel. By doing so, Hurston demonstrates once again how Janie feels empowered by her relationship with nature and acknowledges the need to be a part of it rather than to alienate herself.

Nevertheless, this awakening through nature, as well as Janie's union with the natural world that she observes under the pear tree, is disrupted by her grandmother. Though used as a shield to protect herself from the many forms of her own trauma, Nanny passes her traumatic relationship with nature on to Janie. As trauma has an "ability to transmit 
itself as a sort of viral representation to even an unwilling listener", Nanny's trauma is easily transmitted onto Janie through their conversations - or to be more exact, through Nanny's lectures, which Janie, whether willingly or not, has to listen to (Outka 84). During one of these conversations, Nanny describes the racism African American people have been subjected to, and subsequently compares African American women to mules:

Honey, de white man is de ruler of everything as fur as Ah been able tuh find out. Maybe it's some place way off in de ocean where de black man is in power, but we don't know nothin' but what we see. So de white man throw down de load and tell de nigger man tuh pick it up. He pick it up because he have to, but he don't tote it. He hand it to his womenfolks. De nigger woman is de mule uh de world so fur as Ah can see. Ah been prayin' fuh it tuh be different wid you. Lawd, Lawd, Lawd! (Hurston 14-15)

As Outka argues, this is Janie's "first subjection to the trauma of domesticated animalization" which Nanny imposes on her granddaughter (188). In a few lines, Nanny "teaches" Janie that what she witnessed under her pear tree, where nothing ever was "hierarchically separated", is not the case in the hierarchically separated world that Nanny subjects Janie to (Stein 74). Simply stated, Nanny reinforces the idea that the place of African American women is on the same level as the place of animals and nature - a place hierarchically below not only white men, but also African American men. As Weathers comments, "[d] espite her hatred of it... Nanny complies with the social hierarchy that places black women beneath black men" (203). At the same time, this metaphor also implies what is expected of Janie in her upcoming arranged marriage to Logan Killicks. As Janie herself mentions, "[t]he vision of Logan Killicks was desecrating the pear tree"; this implies that Janie is already aware of how much she will be subjected to patriarchal dominance in her marriage to Killicks (Hurston 14).

By evaluating the origins of Janie's connection to nature and highlighting the transmission of Nanny's trauma to Janie, it becomes clear that although Janie "desires to be close to nature", her experience of the natural world is not purely divine, as was one of her experiences under the pear tree (Aquilone 9). In fact, even if Janie's sexual and emotional freedom is rooted in this experience, it does not alleviate (let alone erase) the abuse and trauma Janie is subjected to not only in the relationship with her grandmother, but also in her relationships with her three husbands. As Outka argues, Nanny's transmission of trauma onto Janie, followed by Janie's marriage to Killicks, "reveal both the radical promise of the natural sublime and the terrible danger of it falling into trauma" (189). That being said, Hurston's use of nature writing is not merely a way of displaying her poetic genius. It is a way to address, or rather to explore, the spaces where nature and race meet - which, undeniably, involves challenging the racist politics that stand behind the "the most historically degrading naturalized stereotypes of African Americans" (Outka 189), as demonstrated through Nanny's animalization of African American women, which becomes a further cause of Janie's exploitation and dehumanization (Maroto 4). 


\section{[3] Connection to the Historical Background of Dehumanization and the Road to Janie's Liberation}

In addition to these critical points regarding the dehumanization of African American women, it would be fitting at this point to highlight the historical, political and social background of the dehumanization of African American people in the South following the end of slavery. This comparison to animals was not reserved solely for African American women. In fact, supporters of the "racist order of slave society", known as the $\mathrm{Ku}$ Klux Klan, widely popularized the stereotypical view of African American men as animals who are unable to control themselves and their sexual urges (Zimring 75). For instance, the Klan's advocate, Thomas Dixon, Jr., a North Carolina native, fought in support of the "white social order" by writing The Leopard's Spots: $A$ Romance of the White Man's Burden, 1865-1900 (1902), a book which, together with other publications by him, "demonized abolitionists and compared black men to animals", yet also entered the list of American best-sellers and became widely known and used against African Americans following its publication (Zimring 75).

The 1915 release of the silent and overly dehumanizing film The Birth of a Nation, directed by D. W. Griffith and approved by the President at the time Woodrow Wilson (an undisguised supporter of racial segregation and white supremacy), only aided this stereotyping of African Americans, as it presented a "heroic image of the Klan as redeemers of a lost and noble South against the threat of animalistic black terror" (Zimring 75). After its release, this visual effort to dehumanize African Americans (extensively popular in the South, but also shown to vast audiences across the North) became ever more prominent, perhaps even aggressive, as proven by "the terrorist violence of the Klan", including racial lynchings (Zimring 76-77).

However, portraying African Americans as a nonhuman "other" was not only a matter of visual or literary arts. Without question, slavery dehumanized African American people - and it was done so in order to reinforce the position of African Americans as slaves, bound by their work on the plantation. This dehumanization began already with enslaved children, who, before reaching the age when they began to work, lived, slept and were given food together with domesticated animals (Ruffin 32-34). As Ruffin explains:

Although some child slaves did not begin work until they were preadolescents, the dehumanizing experience of slavery often reinforced their eventual status as workers on the plantation by grouping enslaved children with domesticated animals. This treatment often thrust the enslaved into an unwelcome proximity with nonhuman nature and underscored that part of their ecological burden would be existing on the margins of the category of human. (33)

Taking both Zimring and Ruffin into consideration, Hurston's writing not only addresses this process of dehumanization; above all, Hurston challenges these "blurred... lines 
between human and nonhuman animal life" (Ruffin 33). In Nanny's conversation with Janie, as she explains the importance of Janie's arranged marriage to Logan Killicks, Nanny uses her memories of slavery and the dehumanization she was subjected to in order to bring Janie to understand how important it is for her to marry. Faced with Janie's begging to let her wait "jus' a lil bit mo", Nanny expresses how she "didn't want to be used for a work-ox and a brood-sow" and "didn't want mah daughter used dat way neither" (Hurston 15). Due to her own traumatizing experiences, what Nanny sees in Janie's connection to nature is not her granddaughter's freedom; instead, she fears that Janie's experience of the natural world, no matter how important to Janie, can "degrade her to the status of a mule" (Outka 191). While Janie observes an ecological exchange in the life of nature under her pear tree, Nanny only sees the threat of Janie's sexual desire. As Maroto adds, Nanny “is convinced that without the 'protection' of a male-owned home, her Janie will face a future of physical and spiritual destruction" (73). However, instead of saving Janie from dehumanization, Nanny only manages to "sell" Janie to Killicks, who treats Janie not as his wife but rather as his servant, even forcing her to work on his land and plow with the help of a "mule all gentled up so even uh woman kin handle 'im" (Hurston 22). In this way, Hurston addresses the "naturalized trauma of slavery" (Outka 192).

However, while Janie successfully escapes a lifetime behind the plow when she runs away with her second husband, Jody Starks, she does not escape mules, nor does she evade the naturalized trauma of slavery. Though Janie recognizes right at the beginning that Jody "did not represent sun-up and pollen and blooming trees", she believes Jody when he says that he does not want to make her his servant in the way Janie's first husband did (Hurston 24). However, Janie's marriage to Jody soon "devolves into object-subject ownership" which degrades Janie into something resembling a Southern slave-owner's wife, whom Jody uses "for his own sense of superiority and ownership", thus making Janie inferior to him while also dehumanizing her (Aquilone 11).

This is well demonstrated in the story of Matt Bonner's abused mule and the subsequent shift in the dynamics between Jody and Janie. In an exchange with Jody, for the first time in front of other people, Janie expresses her joy over the fact that Jody freed Bonner's abused mule:

"Jody, dat wuz uh mighty fine thing fuh you tuh do. 'Tain't everybody would have thought of it, 'cause it ain't no everyday thought. Freein' dat mule makes uh mighty big man outa you. Something like George Washington and Lincoln. Abraham Lincoln, he had de whole United States tuh rule so he freed de Negroes. You got uh town so you freed uh mule. You have tuh have power tuh free things and dat makes you lak uh king uh something." (Hurston 42)

This is the first time Janie speaks in front of other people, an event that both startles and fascinates the people who are present. One of them, Humbo, even exclaims " $[y]$ o' wife is uh born orator" (Hurston 42). Having identified herself in the mule, as Jody treats her "as irreverently as he does the mule", Janie feels such a powerful connection to this 
abused yet free-spirited animal that she breaks her silence in order to celebrate its newfound freedom (Weathers 204). According to Outka, the mule "represents... both the terrible legacy of slavery's natural commodification and the end of Janie's association with speechless and degraded animality" (192). When this mule dies, Janie states that "it was like the end of a war or something like that", indicating that the event causes a shift in the community as well as in Janie's life (Hurston 43). For her, the mule's death suggests the end of "speechless and degraded animality" (Outka 192) and the end of her silent subjugation to her second husband; both ends are complemented by how nature, in the form of hungry buzzards, intrudes on the funeral (designed by Jody to mock the animal) and takes the mule's body for its own.

In the following chapter, the dynamic between Janie and Jody changes instantly, as illustrated in this excerpt from one of their arguments:

"You sho loves to tell me whut to do, but Ah can't tell you nothin' Ah see!"

"Dat's 'cause you need tellin'," he rejoined hotly. "It would be pitiful if Ah didn't. Somebody got to think for women and chillun and chickens and cows. I god, they sho don't think none theirselves."

"Ah knows uh few things, and womenfolks thinks sometimes too!"

"Aw naw they don't. They just think they's thinkin'. When Ah see one thing Ah understands ten. You see ten things and don't understand one." (Hurston 50)

When arguing about the oppression Janie is subjected to in her marriage, Jody compares women (including Janie) and children to "chickens and cows" (Hurston 50). This "dehumanizing" that Ruffin describes as common treatment of (not only) enslaved children (33) functions in the story to degrade the position of both women and children to that of domesticated animals, and it makes Jody seem more like a slaveholder than Janie's husband. However, instead of accepting this treatment and dehumanization in silence, Janie argues with her husband, even telling him that she "knows uh few things, and womenfolks thinks sometimes too" (Hurston 50), thus ending the silent dehumanization of herself and overturning the naturalized trauma into which her moment under the pear tree develops through her first two relationships.

\section{[4] The Impact of the Okeechobee Hurricane: The Journey Back to the City}

This section deals with natural trauma and dehumanization, building on what has been discussed above; however, it focuses specifically on the climax of the novel, the Okeechobee hurricane and its aftermath, as these events also relate to different aspects of environmental racism. Hurricanes are natural disasters, so they do not differentiate between races, genders, classes, nationalities or species; nevertheless, the established social hierarchies and subsequent injustices create barriers between people of different races, genders, sexualities, and classes - and even more so between people and animals. 
Even though such barriers are systemic in their nature, their physical manifestation amidst natural disasters is deadly.

Possibly the most dramatic part of the novel, focusing on the Okeechobee hurricane, takes place in Florida in September 1928. Though Hurston was not present there during this natural disaster, she did experience a hurricane while staying in the Bahamas in 1929. Moreover, being an anthropologist and folklorist, Hurston spent lots of time carrying out extensive interviews with people from the area (Boyd). Having said that, Hurston's description of the hurricane (obviously named after Lake Okeechobee) and its aftermath, though re-told through the eyes of fictional characters, is nevertheless based on real-life experiences. What is more, Their Eyes Were Watching God successfully exposes how the institutionalized structures of racism impact on African Americans before, during and after natural disasters.

For instance, when Janie and Tea Cake attempt to flee the hurricane and leave their cabin in search of higher ground (which is, as it turns out, a terrible idea), Hurston reveals that there were more options for successfully escaping the water - like going to the six-mile bridge, which "was high and safe perhaps" (Hurston 108). In her re-telling of the escape to safety, Janie writes that "[e]verybody was walking the fill", indicating that this was indeed the only possible place where people could hide (Hurston 108). However, despite the despair of people trapped in this life-threatening situation, and despite the obvious presence of babies and old people and their cries for help, this safe place turns out to be completely closed-off for non-white people. As described in the novel:

But it was crowded. White people had preempted that point of elevation and there was no more room. They could climb up one of its high sides and down the other, that was all. Miles further on, still no rest. (Hurston 108)

The fact that non-white people are denied access to a safe place stems from deeply ingrained environmental racism. As demonstrated in the novel, not a single white person comes to warn Tea Cake or Janie about the hurricane. In fact, like Tea Cake and Janie, white people also choose not to leave the Everglades. However, unlike the non-white inhabitants of the Everglades, "white folks" have the privilege and the opportunity to use places like the bridge at Six Mile Bend to save and protect themselves to the point that they are able to crowd the place and make no attempt to help those people who are trapped in the rising waters.

However, the 2005 events of Hurricane Katrina and especially the Levee Disaster prove that the environmental racism which Hurston captures in her novel, and which the inhabitants of the Everglades experienced in 1928, is a prevailing and life-threatening issue in (not only) American society. And although Hurston does not specifically focus on the long-term aftermath of the hurricane in the Everglades, the novel does note that "[m]arginalised people were less likely to be able to evacuate" due to financial and housing reasons, as happened in the case of Katrina and as is demonstrated in Janie and Tea Cake's failed attempt to evacuate and find protection on the bridge at Six Mile Bend (Kaijser and Kronsell 421). Being one of the deadliest hurricanes ever to occur in 
the United States, the 1928 Okeechobee hurricane that Hurston depicts in the novel took the lives of thousands of people and made refugees out of those who survived its wrath. However, because these lowlands of Central Florida were inhabited by predominantly African American communities, who had moved to the Everglades due to the availability of sufficiently remunerative agricultural work, it was they who were most severely affected by the hurricane. This is well demonstrated in the novel's portrayal of the hurricane's immediate aftermath, when African American men (including Tea Cake) as well as white men are forced under the threat of death to carry out the work of burying the dead bodies. While the bodies of white people are buried in proper coffins and graves, the bodies of African American people are hurled into mass graves:

"Hey, dere, y'all! Don't dump dem bodies in de hole lak dat! Examine every last one of 'em and find out if they's white or black."

"Us got tuh handle 'em slow lak dat? God have mussy! In de condition they's in got tuh examine 'em? Whut difference do it make 'bout de color? Dey all needs buryin' in uh hurry."

“Got orders from headquarters. They makin' coffins fuh all de white folks. 'Tain't nothin' but cheap pine, but dat's better'n nothin'. Don't dump no white folks in de hole jus' so.”

"Whut tuh do 'bout de colored folks? Got boxes fuh dem too?"

"Nope. They cain't find enough of 'em tuh go 'round. Jus' sprinkle plenty quicklime over 'em and cover 'em up." (Hurston 112-13)

What Tea Cake experiences once again demonstrates how social hierarchies mean that "vulnerabilities to disaster... are not equally distributed" (Enarson and Morrow 2). However, while these events characterize the "outside" of the environmental racism present in the novel's passage about the hurricane, the fact that both Tea Cake and Janie become more exposed to the disaster (and thus also become more vulnerable during and even after the hurricane than, for instance, the white inhabitants of the Everglades) is also manifested in other moments over the course of Janie's life in the Everglades. Therefore, to better explore the consequences of these vulnerabilities as well as their roots, it is also important to analyze the stages of Janie's life in the Everglades and the impact of racial and environmental inequalities on Janie and Tea Cake's experience of the hurricane.

Before the hurricane arrives, the novel concentrates on Janie's - initially egalitarian - relationship with Tea Cake. Unlike her previous partners, Tea Cake does not wish to alienate Janie from nature, prevent her from enjoying its fruits, or force her to work for him. On the contrary, Tea Cake becomes the closest resemblance to Janie's memory of the pear tree. At the very beginning of their relationship, Janie says that Tea Cake "could be a bee to a blossom-a pear tree blossom in the spring" and even catches herself thinking that "[h] e was a glance from God" (Hurston 73). This perception is based on Tea Cake's love for Janie and the space he shares with her. Instead of making Janie the passive object of his household, an object he owns as property and uses as a servant to "[dip] up the lemonade" for people around them, he squeezes the lemons himself and shares 
the lemonade with Janie (Hurston 70). The making of lemonade is Hurston's metaphor, which serves to show Tea Cake's willingness to accept Janie as his equal partner, and it represents the foundation of Janie's relationship with Tea Cake quite adequately.

According to Aquilone, even after their relationship becomes official, "Tea Cake continues to display an egalitarian mindset towards Janie that mimics the pear tree imagery" (16). Apart from lemonade making, this egalitarian mindset, a form of ecology between the two partners, is also represented in the way in which Janie's connection to nature changes with Tea Cake. As has been highlighted above, Janie's union with Tea Cake does not alienate her from the natural world. The fact that Janie feels that Tea Cake resembles the pear tree imagery, with the possibility of "blossoming", already indicates that Janie feels close to experiencing the poetry of nature, or close to the luxury of enjoying the pure nature, instead of being subjected to degrading animalization and the trauma that stems from it. This dream of having the chance to enjoy the purity and beauty of nature, instead of having to withdraw from such an environment, becomes ever more attainable with Tea Cake's idea of moving to the Everglades.

"We goin' on de muck."

"Whut's de muck, and where is it at?"

"Oh down in de Everglades round Clewiston and Belle Glade where dey raise all dat cane and string-beans and tomatuhs. Folks don't do nothin' down dere but make money and fun and foolishness. We must go dere." (Hurston 86)

Although "de muck" eventually becomes a location where traumatizing events unfold, Tea Cake's first portrayal of the place matches Janie's first impressions as well as the beginning of her life there. During her first moments in the Everglades, Janie herself points out how fertile and unspoiled the land is:

To Janie's strange eyes, everything in the Everglades was big and new. Big Lake Okechobee, big beans, big cane, big weeds, big everything. Weeds that did well to grow waist high up the state were eight and often ten feet tall down there. Ground so rich that everything went wild. Volunteer cane just taking the place. Dirt roads so rich and black that a half mile of it would have fertilized a Kansas wheat field. Wild cane on either side of the road hiding the rest of the world. People wild too. (Hurston 87)

This introduction to the new environment as viewed through Janie's eyes is enough to demonstrate how her previous life in Eatonville, the social isolation as well as the natural alienation that came with it (both caused by her relationship with Jody Starks), turns into "an initially unalienated African American pastoral" as she moves to the Everglades with Tea Cake (Outka 193). While the fact that her new relationship is the closest to the pear tree vision might contribute to the emergence of this pastoral, it is not the only contributing factor. Apart from the peacefulness and fertility (and subsequent agricultural prosperity) the land provides, the house where Janie and Tea Cake live in the Everglades is strikingly different from the one Janie had inhabited with Jody Starks in Eatonville. The Everglades house is a modest cabin which does not position its inhabitants above 
or below other people who live in the community. Thus, the couple find themselves "on the same physical and social level" as others (Maroto 78). Additionally, while working in the pure natural environment of the Everglades, Janie is free to enjoy the area's beauty, eat (and take care of) its fruits, and even learn to "shoot a hawk out of a pine tree and not tear him up" (Hurston 88). Of course, one could criticize the fact that Janie favors hunting hawks; however, after two marriages which ultimately resulted in dehumanization, her character is finally offered a genuine opportunity to stand up to the natural trauma to which she has repeatedly been subjected throughout her life (Outka 193, Hicks 79). Having said that, Janie's settling in the Everglades, her newfound freedom, her love for life and for Tea Cake, as well as her restored connection to nature and resistance to social hierarchies - which she proves by marrying a dark-skinned man and leaving the comfortable life in Eatonville behind - mark her own "fruitful participation in the oral tradition of black culture" (Maroto 79). Through this participation, Janie ultimately "creates spaces of opportunity and redefinition" for herself (Hicks 79). Hurston describes this idyllic and fruitful atmosphere in the novel as follows:

All night now the jooks clanged and clamored. Pianos living three lifetimes in one. Blues made and used right on the spot. Dancing, fighting, singing, crying, laughing, winning and losing love every hour. Work all day for money, fight all night for love. The rich black earth clinging to bodies and biting the skin like ants. (Hurston 88)

Though life is being celebrated to the full, the hurricanes, both from the inside of Janie's relationship as well as from the outside, arrive to disrupt the peaceful atmosphere of the Everglades. Instead of letting the hurricane symbolize merely Janie and Tea Cake's relationship, Hurston also uses it to further address the afflicted relationship of African Americans with nature (Outka 194). This is best illustrated in Tea Cake's reaction to the signs of the forthcoming hurricane and the consequences which result from it. Unlike the Indigenous people and Bahamians, who recognize the signs in nature ("Saw-grass bloom") and move "to high ground" because of a "Hurricane coming" (Hurston 88), Tea Cake decides - without any further consultation with Janie - to stay (Newman 823-824, Outka 194). The reasoning behind this decision is based on his acceptance of the white man's stance that the natural environment can be tamed and controlled, while man always stays unharmed. Therefore, Tea Cake quickly dismisses the Seminoles' knowledge of nature and bases this dismissal on the fact that the Indigenous people own no land. What is more, he also believes that if white people are staying - and if the prices of beans are high - he should stay as well (Newman 823-824):

"Mah uncle come for me. He say hurricane warning out in Palm Beach. Not so bad dere, but man, dis muck is too low and dat big lake is liable tuh bust."

"Ah naw, man. Some boys in dere now talkin' 'bout it. Some of 'em been in de 'Glades fuh years. 'Tain't nothin' but uh lil blow. You'll lose de whole day tuhmorrer tryin' tuh git back out heah."

"De Indians gahn east, man. It’s dangerous." 
“Dey don't always know. Indians don't know much uh nothin', tuh tell de truth. Else dey'd own dis country still. De white folks ain't gone nowhere. Dey oughta know if it's dangerous. You better stay heah, man. Big jumpin' dance tuhnight right heah, when it fair off." (Hurston 103)

The fact that Tea Cake dismisses the signs in nature and the warnings of the Indigenous people brings a turning point in the novel. A character that Hurston portrays as one who is close to nature (even giving him the surname "Woods"), or at least as one who is definitely closer to nature than Janie's previous husbands, is also a character who, overwhelmed with jealousy, ruptures the egalitarian relationship he has with Janie, damages Mrs. Turner's restaurant and, following these two incidents, resorts to adopting "the very white supremacist attitudes" which are designed to dominate over not only nature but also over women and over people of different races, as Tea Cake's dismissal of the Indigenous people shows (Outka 194). Although these attitudes can be viewed as reactions to the long-term violence that Tea Cake has been subjected to in the process of degrading and frequently aggressive attempts to animalize and consequently dehumanize African American men in the United States at the beginning of the $20^{\text {th }}$ century, these attitudes are incorporated into his self in such a significant way that he allows them to influence his decision to risk his and Janie's life.

In the following excerpt, Judie Newman comments on the reasoning behind Tea Cake's decision to stay, and highlights how his behavior here contrasts with his other positive qualities and with how the Seminoles behave while facing the hurricane:

Yet for all his apparent open-handedness, his lack of interest in prestige on white terms, and his ability to function on a footing of equality with Janie, Teacake is still mired in the world of money... Significantly, Teacake's tragic mistake had been to ignore Indian folk knowledge. He discounts the warnings of the local Seminoles that there is a hurricane on the way, in the first place because they are not property-owners... and secondly because of the lure of money. (823)

While Newman emphasizes Tea Cake's desire for money, Erik D. Curren highlights the way in which the Seminoles and Bahamians respond to the hurricane as compared to white people, Tea Cake and the other bean pickers. Similarly to Outka and Newman, Curren emphasizes how the fact that Indians and Bahamians are more in tune with nature makes their behavior in the novel "more rational than white, Western thought", as their "tribal lore" protects them from adopting the same ideologies which breed racial hatred and assumptions that the natural environment can be tamed through a materialistic approach, or through financial and technological means (Curren 19). Such ideologies, or "white culture", as Curren calls it, give birth to white people's racist behavior at the six-mile bridge amidst the worst moments of the storm, and they also give birth to the irrationality that leads Tea Cake to make a decision to not run away from the storm, as well as to prioritize money over his own survival; however, he is not alone in this decision, as white people (though safely evacuated at the six-mile bridge), as well as Tea Cake's fellow bean pickers, are also swayed by "white culture in ways that they do not realize" (Curren 20). 
When the hurricane comes, Janie, Tea Cake and their friend Motor Boat stay in the cabin and play dice, as they have no other option left than to wait for the storm to pass. In contrast to the poetical nature imagery at the beginning of the novel, when Janie explored the world inside her grandmother's garden, Hurston personifies the storm in a way that resembles a living, grandiose human beast that is set to ravage everything in its path:

It woke up old Okechobee and the monster began to roll in his bed. Began to roll and complain like a peevish world on a grumble. The folks in the quarters and the people in the big houses further around the shore heard the big lake and wondered. The people felt uncomfortable but safe because there were the seawalls to chain the senseless monster in his bed. The folks let the people do the thinking. If the castles thought themselves secure, the cabins needn't worry. Their decision was already made as always. Chink up your cracks, shiver in your wet beds and wait on the mercy of the Lord. The bossman might have the thing stopped before morning anyway. (Hurston 104)

In this excerpt, Hurston's use of personification helps to illustrate how frightening the weather must have been, leaving people with no option to do anything but leave their lives in the hands of "the bossman"; at the same time, Hurston alludes to the irrationality of their logic based on trusting the decisions and technologies of white people. However, unlike Janie, Tea Cake and others who stay in the cabins, white people have the "castles" to protect them. The castles can easily refer to the six-mile bridge, a place of higher ground to which the white people evacuate, which ultimately becomes unreachable for Janie and Tea Cake; even the "seawalls" designed "to chain the senseless monster in his bed" become useless for everyone except those who can step onto the treasured drawbridge and enter the castles. Therefore, the passivity of Hurston's characters, their waiting and watching of God, shares the same roots with the kind of passivity that makes the characters stay in the same place and not rescue themselves. Simultaneously, their passivity is not a sign of bravery, but a sign of "internalized white supremacy" which prevents them from seeing the situation as life-threatening and instead feeds them with the false belief that white people, together with God, will be able to take care of their lives and tame the monster in the same way that they always tame nature, or in the same way that they control social hierarchies (Outka 195).

As Tea Cake, Janie and Motor Boat keep waiting, with nothing but "dikes between them and him" (i.e. between them and God), the monster remains untamed. In fact, when the water breaks through "the seawalls" that had prevented Lake Okeechobee from flooding the land, Hurston refers instead to "[t]he monstropolous beast" who wreaks havoc in the muck and has no mercy on houses or the people hiding in them (Hurston 106). This "ecological judgement" also represents nature's attempt to "rebalance" after Tea Cake's disruption of the ecological relationship with Janie (Aquilone 20). According to Aquilone, the fury represented in the personified hurricane, “[ $t]$ he monstropolous beast”, is directed towards Tea Cake as a consequence of his behavior towards Janie (20-21).

While it is possible that the hurricane is a punishment for Tea Cake's behavior (whether his greed or his treatment of Janie), this punishment - ecological judgment - 
has an even deeper meaning: one that is revealed after Tea Cake and Janie try to escape to higher ground. Once again, Tea Cake makes the irrational decision to "make a swim for it", as he falsely expects to be able to access the six-mile bridge. Tea Cake's decision to leave the cabin (where Motor Boat survives the whole hurricane, asleep) stems from how much he believes that he can control the storm and that he can access the castles that have been built to protect white people. As Curren observes, this turn in the novel "shows the ideological cracks - racism, materialism, and a magical belief in the power and goodness of those in authority" (18-19). Ultimately, by deciding to leave their safe place in the cabin, Janie and Tea Cake become embroiled in a "man-against-nature sublime confrontation" that strips away their remaining strength and exposes them to even more dangers than before (Outka 196).

Though the couple are in despair as they escape from the death brought by the storm, Hurston still manages to portray a quite realistic development, with Tea Cake helping Janie swim through the floodwaters and reach the land. Janie then helps the exhausted Tea Cake get some rest, even shielding him with a piece of roof or her own body. Although the way they keep each other alive is courageous, neither Tea Cake or Janie are idealized in these scenes - they do not miraculously find a way to escape the floods and save themselves, and there is no "stereotypical male heroism" (Outka 196); instead, both Janie and Tea Cake are limited by their apparent helplessness in the face of the storm.

Nevertheless, the worst part of this helpless battle with nature - and an even more helpless battle with social hierarchies - comes when Janie, at this point holding onto a cow that is swimming in the turbulent waters, is saved by Tea Cake from being bitten by an unusually aggressive dog:

The dog stood up and growled like a lion, stiff-standing hackles, stiff muscles, teeth uncovered as he lashed up his fury for the charge. Tea Cake split the water like an otter, opening his knife as he dived. The dog raced down the backbone of the cow to the attack and Janie screamed and slipped far back on the tail of the cow, just out of reach of the dog's angry jaws. He wanted to plunge in after her but dreaded the water, somehow. Tea Cake rose out of the water at the cow's rump and seized the dog by the neck. But he was a powerful dog and Tea Cake was over-tired. So he didn't kill the dog with one stroke as he had intended. But the dog couldn't free himself either. They fought and somehow he managed to bite Tea Cake high up on his cheek-bone once. Then Tea Cake finished him and sent him to the bottom to stay there. (Hurston 109)

Unbeknown to Tea Cake or Janie, the dog is infected with rabies, and it passes this infection to Tea Cake. Because rabies may not display its symptoms for year, and because Tea Cake is "so cavalier about the dog bite", they ultimately discover Tea Cake's illness only when he becomes dangerous to those around him (Curren 20). Instead of feeding her readers celebrations of Tea Cake and Janie's survival, Hurston "replays the collapse of sublimity into trauma", as happened in the case of Janie's "dreaming" under the pear tree, followed by Janie's subjugation to animalization at the beginning of the novel (Outka 197). 
The dog bite causes not only Tea Cake's infection, but also his transformation into an aggressive "animal" that threatens Janie's life; in the end, Janie has to kill him in self-defense. The fact that Tea Cake turns into the very same "thing" that African American men have been unjustly accused of for years, the stereotypical portrait of African American men as dangerous "Black Beasts" that threaten white women, is disheartening, yet it shows how ever-present natural trauma is in Janie's life and thus also in the lives of African Americans (Outka 198, Zimring 75). At the same time, as Tea Cake is the one corrupted with greed and Western ideologies, and this can be also viewed as another level of his punishment - while the dog is poisoned with rabies, Tea Cake is poisoned with jealousy, greed, and white culture. Hence, to complete the work of "ecological judgement", Hurston uses a "canis ex machina to dispose of Tea Cake" after he disrupts the egalitarian relationship between him and Janie (Bealer 323).

However, despite his flaws, Tea Cake saves Janie from drowning in the floods and then also from the infectious dog bite. Ultimately, therefore, he becomes a hero - but, instead of living for the rest of his life with Janie on the muck, he is infected with rabies or, as Outka argues, "with the terrible white supremacist history that transformed black men into the Black Beast" (198). Janie's pear tree imagery then vanishes again and is replaced with "the threat of animalistic black terror" in the form of the infected Tea Cake (Zimring 75). As Janie observes, “[h] gave her a look full of blank ferocity and gurgled in his throat... And she was beginning to feel fear of this strange thing in Tea Cake's body" (Hurston 119); this implies that she is aware of Tea Cake's transformation, of the "strange thing" that controls Tea Cake's body and that can potentially cause harm even to her.

In a fight for her own life, Janie is forced to kill Tea Cake. His death is symbolic, as Janie, forced to kill her lover who has become "a bee to her blossom", but who is equally a victim of the dehumanization brought by the post-bellum history, finally breaks the cycle of natural trauma. After the trial which follows Tea Cake's death, Janie is acquitted of all charges. What is more, the trial further highlights Hurston's intention to demonstrate that Tea Cake's death is a death to the trauma that has been unjustly linked with the lives of African Americans:

She tried to make them see how terrible it was that things were fixed so that Tea Cake couldn't come back to himself until he had got rid of that mad dog that was in him and he couldn't get rid of the dog and live. He had to die to get rid of the dog. But she hadn't wanted to kill him. A man is up against a hard game when he must die to beat it. (Hurston 122-23)

Although Janie is not found guilty of murder, the trial itself reveals the systemic injustice that Janie is subjected to. For instance, even though she is a survivor of two traumatic experiences in such a short period of time, while she still managed to take care of her ill husband and even to arrange his funeral, she is described by the white judge as "a poor broken creature", and thus labeled a powerless being (Enarson and Morrow 6). Such labeling makes African American women vulnerable to various forms of violence, as is demonstrated in Janie's experience with her Nanny; by thinking that Janie is too weak 
to be an independent adult, Nanny actually “sold” Janie to become Killick's servant, ultimately destroying her life instead of protecting it.

But Janie's actions were anything but weak. Because she disagrees with sending Tea Cake to the hospital and takes care of him despite the danger of being harmed by him, Tea Cake is able to bite into Janie's arm. Of course, there is a possibility that Janie has not become infected; however, Hurston purposefully decides to not specify Janie's fate and instead leaves her readers wondering whether Tea Cake Janie's final independence and life in connection with nature as revealed at the end of the novel is the poetical end, a victory over years of natural trauma, or whether it instead points to the inevitability of "endless violence and animalized trauma" that the story undoubtedly - and for a good reason - highlights (Outka 200).

\section{[5] Conclusion}

The aim of this article has been to address depictions of environmental racism as well as depictions of the sexist-naturist, degrading (or, on the other hand, empowering) portrayal of African American women as nature or as animals in Zora Neale Hurston's Their Eyes Were Watching God, and to evaluate this novel within the context of critical ecofeminist and ecocritical theories, analyzing the impact of environmental as well as institutional racism on the lives of African American women and other characters portrayed in the novel.

The analysis itself focuses on Janie's relationship with her grandmother as well as her three husbands, with the goal of identifying dehumanization and subsequent natural trauma; it analyzes these concepts in the historical, political and social context of environmental and institutional racism in the United States of America. The paper demonstrates that Hurston uses the woman/nature metaphor throughout the whole novel in order to depict Janie's journey towards independence; however, as the analysis shows, this journey above all involves a struggle against degrading animality, natural and intergenerational trauma, racism and extreme vulnerability amidst an environmental disaster. The analysis reveals that, although Hurston uses poetical nature imagery and metaphors to highlight Janie's need for a peaceful connection with nature, which would empower her on her journey towards independence, this connection can easily slip into dehumanization and related trauma caused by animalization - which may influence characters' relationship with nature and animals for the rest of their lives.

While the impact of nature writers such as Muir, Steinbeck, Blake or Thoreau has been well evaluated and canonized in ecocritical circles, there is also an ongoing and significant discussion about the importance of African American female writers like Hurston, who are now thankfully being recognized for their critical input on the devastation of the natural environment, natural trauma and its relation to institutional racism. Voices such as Hurston's represent a significant contribution to both ecocritical and ecofeminist literary critique, not only because Hurston writes about environmental racism, but also because she represents the voices of African Americans who should not be excluded from any part of the environmental or ecofeminist movements. 


\section{[Bibliography]}

Alquilone, Victoria. "Ecological Landmarks in Zora Neale Hurston's Their Eyes Were Watching God: An Ecofeminist Reading.” Concept 40 (2017): 1-24. Web. 2 February 2021. https://concept.journals.villanova.edu/index.php/concept/article/ view/2196/2008

Bealer, Tracy L. “'The Kiss of Memory': The Problem of Love in Hurston's Their Eyes Were Watching God." African American Review 43.2-3 (2009): 311-327.

Boyd, Valerie. “A Protofeminist Postcard from Haiti.” Zora Neale Hurston. 2 Apr. 2018. Web. 18 Aug. 2021.

Curren, Erik D. “Should Their Eyes Have Been Watching God?: Hurston's Use of Religious Experience and Gothic Horror.” African American Review 29.1 (1995): 17-25, doi: $10.2307 / 3042424$.

Enarson, Elaine Pitt, and Betty Hearn Morrow. The Gendered Terrain of Disaster: Through Women's Eyes. Westport CT: Praeger Press, 1998.

Gaard, Greta. Critical Ecofeminism. Lanham: Lexington Books, 2019.

Hemenway, Robert. Zora Neale Hurston: A Literary Biography. Illinois: Illini Books, 1980.

Hicks, Scott. "Rethinking King Cotton: George W. Lee, Zora Neale Hurston, and Global/ local Revisions of the South and the Nation." Arizona Quarterly: A Journal of American Literature, Culture, and Theory 65.4 (2009): 63-91, doi: 10.1353/arq.0.0052.

Hurston, Zora N. Their Eyes Were Watching God. New York: HarperCollins, 2006.

Kaijser, Anna, and Annica Kronsell. "Climate Change through the Lens of Intersectionality.” Environmental Politics 23.3 (2013): 417-33.

Maroto, Inés Casas. “'So This Was A Marriage!': Intersections of Natural Imagery and the Semiotics of Space in Zora Neale Hurston's Their Eyes Were Watching God." Journal of English Studies 11 (2013): 69-82, doi: 10.1080/09644016.2013.835203.

Newman, Judie. “'Dis Ain’t Gimme, Florida': Zora Neale Hurston's ‘Their Eyes Were Watching God'.” The Modern Language Review 98.4 (2003): 817-26, doi:10.2307/3737926.

Outka, Paul. Race and Nature from Transcendentalism to the Harlem Renaissance. London: Palgrave Macmillan, 2008.

Ruffin, Kimberly. Black on Earth: African American Ecoliterary Traditions. Athens: University of Georgia Press, 2010.

Stein, Rachel. "Re-rooting the Sacred Tree: Nature, Black Women, and Voodoo in Zora Neale Hurston's Tell My Horse and Their Eyes Were Watching God.” Shifting the Ground: American Women Writers' Revisions of Nature, Gender, and Race. By Rachel Stein. Charlottesville, VA: U of Virginia, 1997. 53-83.

Walker, Alice.Living by the Word: Selected Writings, 1973-1987. London: Phoenix Books, 2005. Weathers, Glenda B. "Biblical Trees, Biblical Deliverance: Literary Landscapes of Zora Neale Hurston and Toni Morrison." African American Review 39.1-2 (2005): 201-212. Zimring, Carl A. Clean and White: A History of Environmental Racism in the United States. New York City: New York University Press, 2017. 


\section{[Address]}

Department of English and American Studies

Faculty of Arts

University of Ostrava

Reální 5,

70103 Ostrava

Czech Republic

karlarohova@gmail.com

Karla Rohová graduated from the University of Ostrava with a Master's degree in English Philology. In both her studies and her publications, she focuses on the examination of literary works from ecofeminist and ecocritical perspectives. Apart from English and American studies, she also devotes her time to creative writing, especially to poetry. 